DOI https://doi.org/10.30525/978-9934-588-91-4-15

\title{
ДОКУМЕНТИ 3 ІСТОРІЇ ОБОРОННИХ БОЇВ 6-ї \\ ТА 12-ї РАДЯНСЬКИХ АРМІЙ ВЛІТКУ 1941 РОКУ \\ У ФОНДАХ ЦЕНТРАЛЬНОГО АРХІВУ \\ МІНІСТЕРСТВА ОБОРОНИ РОСІЙСЬКОЇ ФЕДЕРАЦІЇ
}

\author{
Москальчук К. В. \\ аспірантка кафедри всесвітньої історії \\ Центральноукраїнського державного педагогічного університету \\ імені Володимира Винниченка \\ м. Кропивницький, Украӥна
}

Оборонні бої радянських 6-ї та 12-ї армій влітку 1941 року тривалий час залишались поза межами історичних досліджень. Партійне керівництво СРСР та Головне політуправління Червоної Армії не могли допустити витоку інформації про причини поразок на фронтах в перші місяці німецько-радянської війни. Тому більшість бойових документів зберігались у так званому спеціальному сховищі, доступ до якого мало обмежене коло осіб.

У СРСР діяла різнорівнева система секретності стосовно архівної та поточної документації. Найнижчий рівень засекреченості мали документи 3 позначкою - «Для службового користування». Вони не публікувалися для широкого загалу, але були доступні для спеціалістів різних галузей, зазвичай це були матеріали, що містили не державну, а службову таємницю. Наступні рівні - це документи з грифами «Секретно», «Цілком таємно» та «Особливої важливості». За розголошення інформації з них законодавством СРСР передбачалася кримінальна відповідальність. Для доступу до матеріалів 3 вказаними грифами потрібно було отримати спеціальний дозвіл і підписати документи про нерозголошення змісту [9, с. 11].

Вперше документи пов'язані з подіями на Південно-Західному та Південному фронтах були опубліковані в «Сборнике боевых документов Великой Отечественной войны». Збірник не був доступний для дослідників, його інформативний потенціал використовувався для підготовки старшого та вищого офіцерського складу, які були слухачами Військової академії імені М. В. Фрунзе. Усі документи, що були опубліковані у збірнику зберігались у фондах Центрального архіву Міністерства оборони СРСР (нині Центральний архів Міністерства оборони РФ).

На початку 1990-х років в СРСР, а згодом в Російській Федерації, було започатковано створення законодавчої бази, стосовно регулювання архівної справи. Звичайно, розпад СРСР не означав відкриття абсолют- 
но всіх архівних фондів. Навіть сьогодні частина фондів ЦАМО РФ $є$ засекреченими, не дивлячись на наказ Міністра оборони Російської Федерації від 8 травня 2007 р. № 181 «О рассекречивании архивных документов Красной Армии и Военно-Морского Флота за период Великой Отечественной войны 1941 - 1945 годов» [8].

Ряд архівних документів були позбавлені грифу «Цілком таємно», але дослідники й досі ще мають перепони під час роботи і з архівними колекціями, і з документами. Для прикладу, ЦАМО РФ не має єдиного науково-довідкового апарату, тобто ті хто працюють з фондами архіву не мають змоги опрацювати путівники та описи фондів. Частина документів, що зберігаються у фондах, фактично залишаються не доступними, як такі, що дискредитують Збройні сили СРСР. Також відсутній чіткий механізм розсекречення матеріалів. Відповідно до інструкції щодо роботи в ЦАМО РФ, працювати з матеріалами з фондів архіву мають право тільки громадяни Російської Федерації. Але разом із тим значна частина документів ЦАМО РФ оцифровані та доступні у Всесвітній павутині.

Працюючи 3 архівними документами, які є доступними завдяки електронним базам даним, нам вдалось встановити, що не всі документи стосовно історії участі в оборонних боях 6-ї та 12-ї армії були опублікованими в «Сборнике боевых документов Великой Отечественной войны».

Оскільки в ЦАМО РФ відсутній офіційний перелік фондів, нам у ході дослідження вдалось встановити номери та назви фондів, у яких зберігаються документи пов'язані 3 оборонними боями 6-ї та 12-ї армій влітку 1941 року. Так, Ф. 228 - це документи Південного фронту (I формування, 21 червня 1941 р. - 28 липня 1942 р.), Ф. 229 Південно-Західного фронту (I формування, 21 червня 1941 р. 12 липня 1942 р.), Ф. 251 - Польового управління Південно-Західного напрямку (10 липня - вересень 1941 р.), Ф. 334 - документи 6-ї армії (I формування, 22 червня - 10 серпня 1941 р.), Ф. 3041 - документи 49-ї танкової дивізії, Ф. 839 - 13-го стрілецького корпусу, Ф. 851 17-го стрілецького корпусу. Нам не вдалося встановити назву Ф. 701, у межах якого зустрічаються документи пов'язані, як з 6-ю так і 3 12-ю арміями Як бачимо, в архіві відсутній окремий фонд 12-ї армії або фонд об'єднаної «групи Понєдєліна». Це можна пояснити тим, що в умовах повного оточення пріоритетом для генерал-майора П. Г. Понєдєліна був прорив з оточення, а не збереження і передача бойових документів у штаб фронту.

Виявлені у фондах ЦАМО РФ документи ми поділили на кілька груп. Документи i матеріали Ставки Головного Командування ( 10 липня 1941 р. - Ставка Верховного Командування, 38 серпня 1941 р. - Ставка Верховного Головнокомандування). В основному цей масив документів складають директиви Ставки про організацію 
оборони та відведення сил, адресовані штабам фронтів. Наступну групу складають документи польового управління Головного командування Південно-Західного напрямку та документи штабу Головного Командування Південно-Західного напрямку (Південно-Західний напрямок був створений 10 липня 1941 р. під командуванням С. М. Будьонного). Також досліджено групу документів штабів армій, корпусів та дивізій [7, c. $47-48]$.

До неопублікованих документів з ЦАМО РФ належать журнали бойових дій (далі - ЖБД), у яких фіксується процес підготовки та хід військових операцій. Журнали бойових дій не публікувались, оскільки вони є достатньо об'ємними. Нами виявлено 12 журналів. 3 них три охоплюють бойові дії на Південно-Західному фронті - «Журнал боевых действий и учета боевого состава ВВС ЮЗФ № 3 с 22.07.41 г. по 06.08 .41 г.» [3], «Журнал боевых действий и учета боевого состава ВВС ЮЗФ с 01.07.41 г. по 21.07.41 г.» [4] «Журнал боевых действий ЮЗФ с 21.07.41 г. по 05.08.41 г.» [6]. Саме в них найбільш детально зафіксовано бойові дії за участі 6-ї та 12-ї армії у червні - серпні 1941 року. Особливістю цього типу документів $є$ те, що окрім опису дій радянської армії в кінці кожного дня подані зведені дані щодо дій німецьких військових з'єднань. Окрім цього, нам вдалося виявити журнали бойових дій Південного фронту та відповідні журнали окремих військових з'єднань $[1,2]$. Незважаючи на те, що у ЖБД інформація викладена у короткому варіанті по кожному дню, їхня інформативна цінність надзвичайно висока, оскільки ці документи дозволяють встановити хронологічну послідовність подій та локалізувати окремі військові сутички.

Окрему групу архівних документів складають картографічні матеріали, які доволі часто додаються до ЖБД. Проаналізувавши наявну літератури за темою нашого дослідження, ми дійшли висновку, що серед істориків саме військово-штабні (оперативні) карти залишаються найменш популярним історико-документальним матеріалом. Загалом нами виявлено 33 карти, які раніше не залучались при дослідженні історії бойових шляхів 6-ї та 12-ї армії на початковому етапі німецькорадянської війни. Переважну більшість складають робочі карти оперативного відділу Південно-Західного та Південного фронтів, а саме 17 оперативних карт.

Характерною особливістю картографічних джерел є те, що в них значний обсяг інформації поданий у компактній формі за допомогою умовних позначень. Складність роботи 3 робочими військовими картами полягає у тому, що вони не мають легенди і охоплюють велику територію, оскільки відтворюють події по всій лінії фронту.

Картографічні джерела найкраще використовувати у комплексі 3 писемними джерелами, оскільки вони візуалізують описані факти. Також для отримання достовірної інформації радянські військові карти 
потрібно вивчати, порівнюючи з відповідною німецькою картографією. Комп'ютерні технології дозволяють накласти військові карти 1941 року на сучасні, що дає змогу точно локалізувати місця бойових дій. Даний метод є корисним, оскільки деякі населенні пункти після війни зникли, а деякі були перейменовані.

Отже, неопубліковані джерела 3 історії оборонних боїв 6-ї та 12-ї армій влітку 1941 року на Південно-Західному та Південному фронтах охоплюють потужний масив різнопланових документів. Розсекречення архівних матеріалів 3 фондів Центрального архіву Міністерства оборони Російської Федерації у 1990-х - 2000-х роках дає змогу деталізувати проблему трагедії 6-ї та 12-ї радянських армій влітку 1941 року.

\section{Література:}

1. Журнал боевых действий войск Южного фронта с 15.07 .41 г. по 28.07.41 г. - ЦАМО РФ. - Ф. 228. - Оп. 701. - Од. зб. 229. - Арк. 1-48.

2. Журнал боевых действий войск Южного фронта с 29.07.41 г. по 06.09.41 г. - ЦАМО РФ. - Ф. 229. - Оп. 701. - Од. зб. 232. - Арк. 1-113.

3. Журнал боевых действий и учета боевого состава ВВС ЮЗФ № 3 с 22.07 .41 г. по 06.08.41 г. - ЦАМО РФ. - Ф. 229. - Оп. 0000181. Од. зб. 0050. - Арк. 1-89.

4. Журнал боевых действий и учета боевого состава ВВС ЮЗФ с 01.07.41 г. по 21.07. 41 г. - ЦАМО РФ. - Ф. 229. - Оп. 0000181. - Од. зб. 0048. - Арк. 1-79.

5. Журнал боевых действий Южного фронта с 24.06.41 г. по 20.08. 41 г. - ЦАМО РФ. - Ф. 228. - Оп. 701. - Од. зб. 228. - Арк. 1-105.

6. Журнал боевых действий ЮЗФ с 21.07.41 г. по 05.08.41 г. ЦАМО РФ. - Ф. 229. - Оп. 161. - Од. зб. 176. - Арк. 1-83.

7. Нуждин О. Битва под Уманью: трагедия 6-й и 12-й армий (25 июля - 7 августа 1941 г.): [монография]. - Екатеринбург: Изд-во Урал. Ун-та, 2011. - 328 с.

8. О рассекречивании архивных документов Красной Армии и Военно-Морского Флота за период Великой Отечественной войны 1941-1945 годов: Приказ Министра обороны Российской Федерации от 8 мая 2007 г. № 181 г. URL: https://rg.ru/2007/06/20/grify-dok.html (Дата звереннення: 10.10 .2020 р.).

9. Перечень сведений, запрещенных к опубликованию в открытой печати, передачах по радио и телевидению. - М., 1974. - 108 с. 